\title{
Immune Mechanisms in Choroido-retinal Inflammation in Man
}

\author{
SUSAN LIGHTMAN* and CHI-CHAO CHAN** \\ London and Bethesda, USA
}

\begin{abstract}
Summary
The immunohistopathological findings of enucleated eyes and immunological abnormalities in several clinical disorders which result in intraocular inflammation are presented. With current immunological techniques, it is possible to define the type and activation status of the cells infiltrating the tissues. In all eyes examined, the predominant cell type was of activated CD4+ T-cells suggesting that the mechanisms involved in the perpetuation of the inflammatory response are similar and it is the initiating events which are likely to determine the site of pathology. The effects of activated CD4+ T-cells and the lymphokines they secrete in the chronic inflammatory process in the ocular tissues are discussed.
\end{abstract}

Ocular inflammation can occur in patients with systemic disorders such as sarcoidosis and Behçet's disease or can be localised to the eyes as in sympathetic ophthalmia and pars planitis. Many of these disorders have characteristic features recognisable clinically but the causes are unknown. The patient often requires immunosuppressive therapy to control the inflammatory response so as to limit the damage to the ocular tissue. Autoimmune mechanisms are thought to be involved in the initiation and/or perpetuation of the inflammatory response although the exact role in the pathogenesis is unknown. With the advent of immunohistochemical staining with monoclonal antibodies to cell surface markers, much more is now known about the cell types infiltrating the inflamed eyes in these conditions.

Many of the inflamed eyes which have been examined immunohistopathologically have been enucleated at the end stages of the disease processes, after the development of complications and/or after systemic immunosuppressive therapy. The findings are therefore of one time point and may reflect different pathology to that seen in the acute phase of the disease. With that proviso in mind, the findings in several clinically recognised ocular inflammatory states will be presented and discussed.

\section{Sympathetic Ophthalmia}

This disorder has been known about since the time of Hippocrates and the initiating factors are still not known. It is defined as a bilateral inflammation of the entire uveal tract which follows perforating injury to one eye, either in the form of trauma from a penetrating injury or following intraocular surgery. In $90 \%$ of cases, the inflammation occurs within one year of the injury with $65 \%$ occurring within the first two months. ${ }^{1}$ More uncommonly many years may elapse before the onset of the

From: *Institute of Ophthalmology, Moorfield's Eye Hospital, City Road, London.

** Laboratory of Immunology, National Eye Institute, National Institutes of Health, Bethesda, MD 20892, USA.

Correspondence to: Dr Susan Lightman, Institute of Ophthalmology, Moorfield's Eye Hospital, City Road, London EC1V 2PD. 


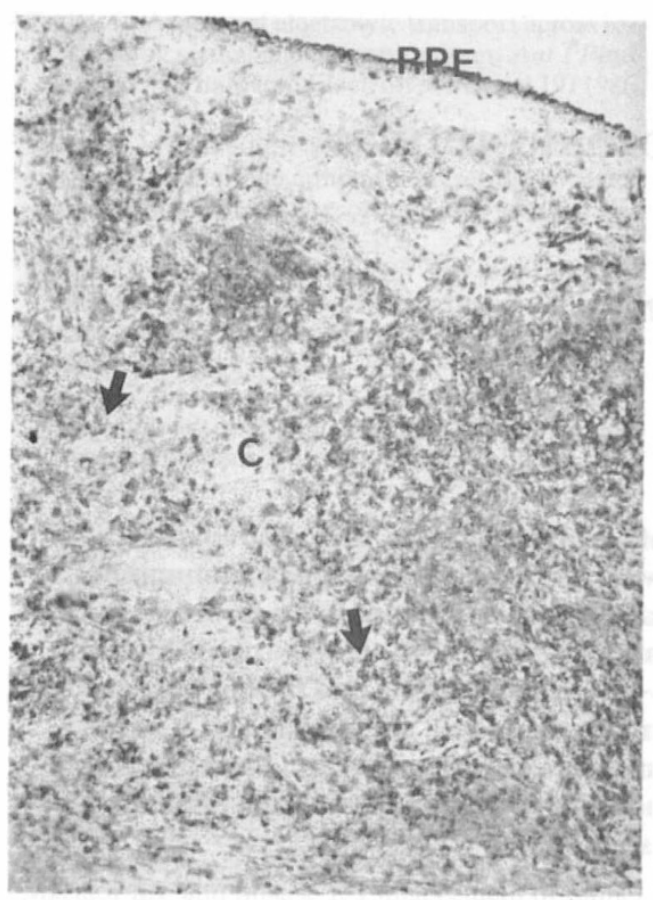

Fig. $1 \mathbf{a}$ inflammatory process. Clinically, there is a bilateral panuveitis with choroidal thickening and optic nerve swelling. Dalen-Fuchs nodules characteristically occur in the periphery and appear as whitish-yellow spots at the level of the retinal pigment epithelium (RPE) ${ }^{2}$ The disease usually follows a relapsing course and treatment is aimed at immunosuppression usually with steroids in the first instance but other drugs such as azothiaprine, cyclophosphamide and cyclosporin maybe useful. ${ }^{3}$

Histopathologically, there is a diffuse nonnecrotising granulomatous inflammation of the uvea with marked thickening of the choroid and relative sparing of the retina and choriocapillaris with similar appearances seen in both the injured and the sympathising eye. The choroid is infiltrated by lymphocytes with nests of macrophages, epitheloid and giant cells. Dalen-Fuchs nodules, seen in $30-100 \%$ of cases examined depending on the series, consist mainly of epitheloid cells located between Bruch's membrane and the RPE. ${ }^{4}$

In an American series, $32 \%$ of 28 patients with sympatheltic ophthalmia were found to

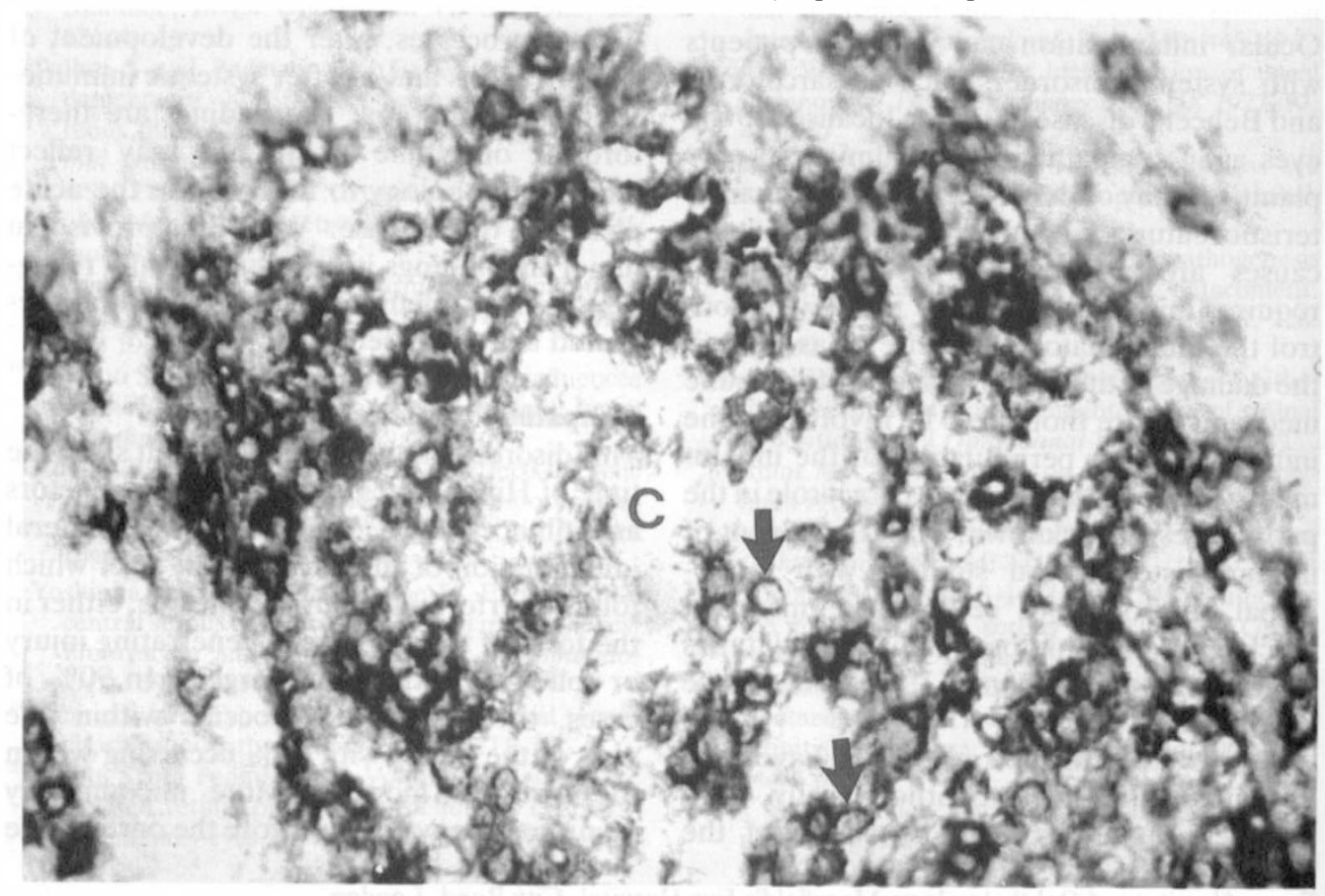

Fig. Ib

Fig. 1. Sympathetic ophthalm,ia-early (a) and late stages (b). Choroid infiltrated with T-cells (arrows) of the $C D 4+$ type (a) and CD8+ type (b). C=choroid $R P E=$ retinal pigment epithelium. Frozen section. $\times 400(a) \times 800$ (b). 
have the HLA-A11 antigen as compared to $4 \%$ of 107 patients with ocular perforation but without sympathetic ophthalmia. The antigens HLA-DR4 and HLA-DRW53 were found to be highly associated with sympathetic ophthalmia in Japanese patients. ${ }^{6}$ Histologic variants related to race have been reported between black and white American patients with sympathetic ophthalmia ${ }^{7}$ but no difference was seen between Chinese and American patients. ${ }^{8}$

Immunohistopathologic studies of sympathetic ophthalmia demonstrate that the choroid is infiltrated mainly by T-lymphoctes with a small number of B-cells and plasma cells. ${ }^{9-11}$ In the eyes enucleated early in the disease process, the T-cells were mainly of the CD4+ type ${ }^{12}$ (Fig. 1a) and of the CD8+ type in later stages (Fig. 1b). In most series, there was no alteration of the T-cell populations in the patient's blood..$^{9,11,13}$ The epithelioid cells in Dalen-Fuchs nodules express class II MHC antigens (HLA-DR) and have the staining characteristics of bone-marrow derived histiocytes. ${ }^{9,10,11,14}$ They may be involved in presenting ocular antigens to T-cells. The T-cell infiltration suggests that it is the cellular rather than the humoral arm of the immune response which is predominately activated. This was suggested previously by the demonstration of lymphocyte transformation to crude extracts of uveoretinal tissue ${ }^{15}$ in patients with this disease.

The inciting antigen in sympathetic ophthalmia is still not known. Neither uveal melanin or uveal homogenates are immunogenic $^{16}$ but retinal extracts and in particular retinal S-antigen ${ }^{17}$ and interphotoreceptor binding protein (IRBP) ${ }^{18}$ are highly antigenic and are able to induce uveoretinitis in experimental animals, ${ }^{19}$ which can mimic several features of sympathetic ophthalmia, when given with adjuvants. ${ }^{20}$ Exactly how relevant these antigens are in man is unknown. It is possible that penetrating trauma, however, caused, may result in the exposure of uveoretinal antigens to conjunctival lymphatics, ${ }^{21}$ with infectious agents such as bacteria and viruses in genetically susceptible individuals acting as adjuvants for induction of the disease. ${ }^{22,23}$

Vogt-Koyanagi-Harada's (VKH) Syndrome This syndrome occurs more frequently in
Orientals where it accounts for $8 \%$ of uveitis patients $^{24}$ but in Americans only $1-4 \%$ of uveitis patients were diagnosed as having the VKH syndrome. ${ }^{25}$ The panuveitis may be preceded by a prodromal phase characterised by headaches, orbital pain, meningism, nausea and examination of the CSF may show a pleocytosis. Ocular involvement is usually bilateral, although one eye may present first, and is associated with a panuveitis, optic nerve swelling, serous detachment of the retina and infiltration of both the choroid and RPE. Poliosis, vitiligo, alopecia, dysacousia may also occur. The retina reattaches with a mottled appearance and there may be chorioretinal scarring. ${ }^{25,26}$ Systemic involvement is not associated with a worse visual prognosis. ${ }^{25}$

In Japan, a study of 185 patients with VKH were reported to express the HLA-DRW53 antigen and there was increased expression of HLA-DR4 and HLA-DQWa as compared to controls. ${ }^{27}$ HLA typing of 17 American patients with VKH did not reveal any strong associations. $^{28}$

Histopathological examination demonstrates many features of sympathetic ophthalmia but also obliteration of the choriocapillaris, focal active chorioretinitis and marked involvement of the RPE ${ }^{29,30}$ In a patient with longstanding disease, T-lymphocyte infiltration was seen in the uvea and retina but in contrast to sympathetic ophthalmia, foci of aggregated B-lymphocytes were also seen. ${ }^{31}$ An increase in serum IgD has also been reported. ${ }^{32}$ Limbal biopsies in patients with VKH demonstrated an increase in CD4+ T-cells in early stages of the disease and an increase in CD8+ cells at a later stage.$^{33}$ T-cells have also been found in the CSF and in skin lesions ${ }^{33}$ and an increase in interferon- $\gamma$ has been demonstrated in the serum and CSF of patients with VKH ${ }^{27}$ Antibodies to ganglioside, ${ }^{28}$ outer segments of the photoreceptors and Müller cells ${ }^{34}$ have all been detected as has evidence for cellmediated immunity to myelin basic protein ${ }^{35}$ and melanin. ${ }^{36}$ It is postulated that an unknown agent such as a virus may trigger an autoimmune reaction to the melanocytes and/or neuronal elements.

\section{Pars Planitis}

This chronic ocular inflammatory disorder is 


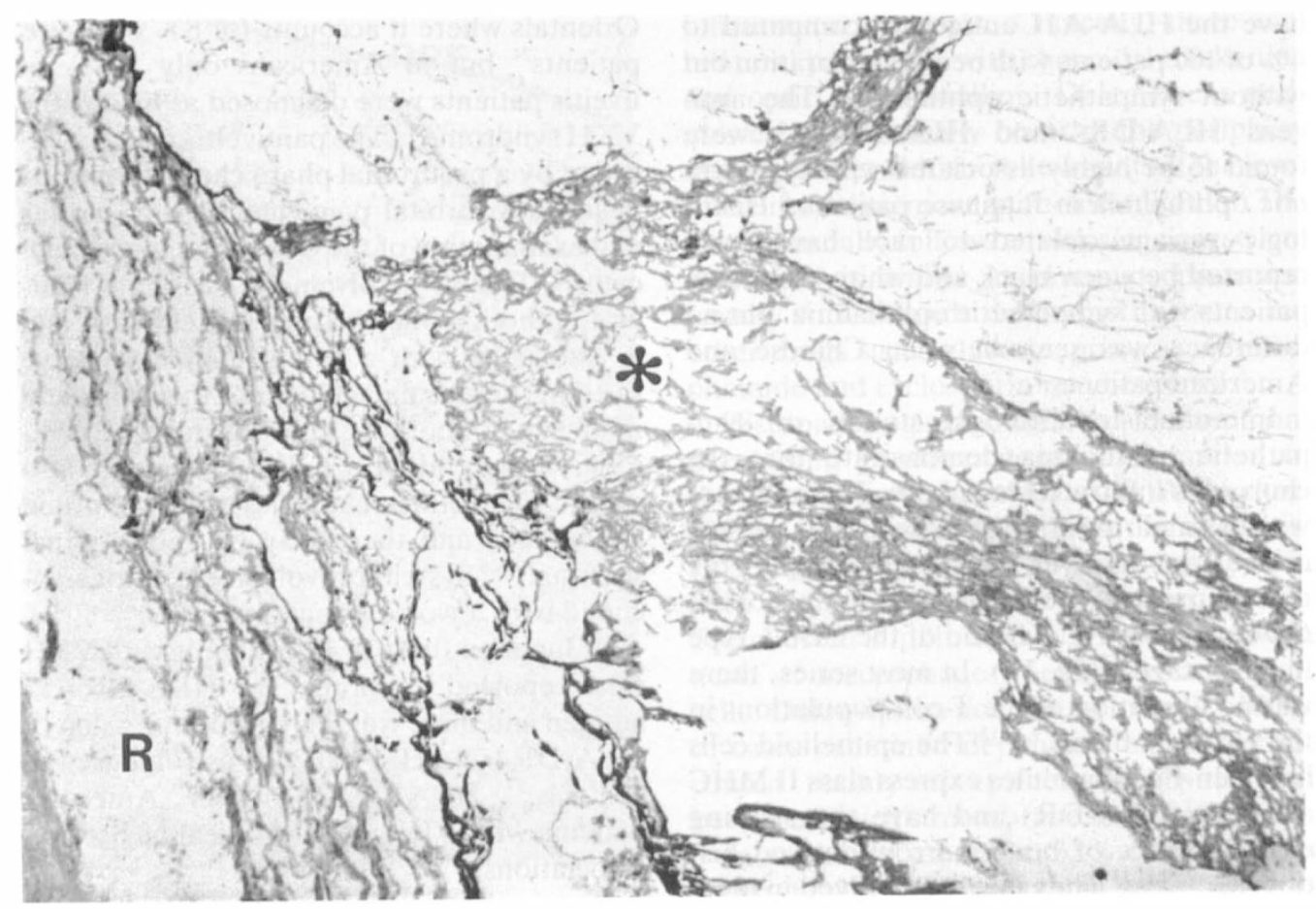

Fig. 2. Pars planitis. Immunohistochemical examination showed the main component (star) staining positively for GFA P monoclonal antibody. R-retina. Frozen section $\times 100$.

characterised by 'snowbanks' overlying the pars plana, occurring particularly in children and young adults. ${ }^{37}$ There is often optic nerve swelling and macular oedema with patchy leakage from the retinal veins demonstrable on fluorescein angiography. ${ }^{38}$ Neovascularisation may occur in the region of the snow bank which can result in pre-retinal membrane formation and subsequently to traction retinal detachment. No genetic linkage to HLA loci has been identified although there have been reports of the disease occurring in siblings. ${ }^{39}$

Enucleated eyes have demonstrated detachment and collapse of the vitreous body with fibrous organisation of the vitreous base. $^{40}$ Either no significant choroiditis or small focal areas of peripheral choroiditis were seen with low grade lymphocytic infiltration of the pars plana.$^{41}$ Examination of the snow bank showed that it contained vascularised condensed vitreous collagen with interspersed chronic inflammatory cells and hyperplastic non-pigmented ciliary epithelium together with fibroglial tissue. It was suggested that the snowbank arose from a common inflammatory process involving both the peripheral retina and the vitreous base. ${ }^{42}$

An immunohistopathological study of an eye with end-stage pars planitis demonstrated an influx of CD4 + T-cells into the pars plana, snowbank and around the retinal vessels. ${ }^{43}$ Few of the T-cells had demonstrable IL-2 receptors. Normal peripheral blood T-cell populations were found. B-cells were seen in the iris and ciliary body but not in the snowbank or pars plana. The snowbank stained heavily with antibodies against glial fibrillary acid protein (GFAP) and Müller cells (Fig. 2) suggesting that glial elements are involved in the snowbank. Type IV collagen and laminin were the major collagen glycoproteins in the snowbank and these are known to be formed by glial cells rather than fibroblasts. ${ }^{42}$ This suggests that the snowbank may be formed from glial elements in the peripheral retina.

Müller cells are known to proliferate in vitro in response to factors produced by activated $\mathrm{T}$-cells ${ }^{44}$ suggesting that the snowbank formation might be stimulated by the inflammatory process. These cells can also present 
antigens to T-cells ${ }^{45}$ and therefore can contribute themselves to the inflammatory process. Why this type of ocular inflammation stimulates a glial response whereas it is uncommon in other types is completely unknown.

\section{Sarcoidosis}

Sarcoidosis is a systemic granulomatous disorder of unknown aetiology. ${ }^{46}$ Hilar lymphadenopathy and pulmonary infiltration are common findings but many organ systems can become involved including skin, joints, liver and central nervous system. In the eye there is usually an anterior uveitis classically with mutton-fat keratic precipitates, vitritis and retinal vasculitis. ${ }^{47}$ The retinal vessels may be sheathed and show patchy leakage of dye on fluorescein angiography. Branch vein occlusions can occur. Retinal and macular oedema may occur and retinal granulomas may extend into and involve the choroid. ${ }^{48,49}$ The optic nerves can be involved by extension from the retinal inflammatory process, by granulomas primarly affecting the nerve itself or from raised intracranial pressure due to $\mathrm{CNS}$ involvement.

In the peripheral blood, there is a generalised lymphopenia with a marked reduction in the number of T-helper cells, a decreased response to mitogens and depressed B-cell function. ${ }^{50}$ Histopathologically, sarcoidosis is characterised by non-caseating granulomas mainly composed of macrophages, epithelioid cells and giant cells surrounded by a rim of lymphocytes. ${ }^{46}$ An infiltrate of CD4+ T-cells was found in the lungs, liver, skin, lymph nodes and conjunctiva of patients with active sarcoidosis. $^{51}$

An eye from a patient with active sarcoidosis was enucleated as it had become blind and painful as a result of severe intraocular inflammation and underwent immunohistopathological examination. ${ }^{52}$ Within the granulomas found in the retina and uvea, $90 \%$ of the T-cells were of the CD4+ phenotype (Fig. 3). Less than $10 \%$ of the total T-cells were CD $8+$ and these were confined to the lymphocyte cuff and were not within the granulomas. Lymphocytes both within and around the granuloma had demonstrable IL-2 receptors as did the epithelioid and giant cells. Class II MHC antigens were diffusely distributed over the granuloma. T-cells and activated macrophages were closely associated within the granuloma and binding of anti-interferon- $\gamma$ antibody was found in the granuloma. Very few B-cells were seen and those were at the periphery of the granulomas. These findings suggest that the T-cells seen in the granulomas are activated and secreting both IL- 2 and interferon- $\gamma$. The macrophages were found to express class II MHC antigens suggesting that they are involved in antigen presentation to the T-cells.

A ring of CD8 + cells was present surrounding the granuloma and it is tempting to think that these cells are acting to restrict the cellmediated immune response. ${ }^{53.54}$ The tissue findings including those described in the eye, suggest that sarcoidosis is a disease of heightened cell-mediated immune activity in affected tissues. This results in massive recruitment of CD4+ T-cells from the peripheral blood and the cutaneous energy seen on PPD testing in patients previously immunised with $\mathrm{BCG} .{ }^{55}$

\section{Behçets Disease}

This disorder is characterised by an occlusive vasculitis and can affect many different organ systems. There are several forms of this disease which can overlap. The type of disease with mainly ocular features is said to be associated with HLA B51, a sub-type of B5. ${ }^{56}$ HLA-B12 is associated with the type which affects mainly the skin and mucous membranes. ${ }^{57}$ All forms may be associated with mouth ulceration which is a classic diagnostic feature. The ocular disease is characterised by a panuveitis and occlusive retinal vasculitis, classically with hypopyon. ${ }^{58} \mathrm{~A}$ viral cause, particularly a herpes virus, has been implicated many times as the causative agent in Behçets disease. ${ }^{59,60}$ but this remains unproven. However, whether the disease process is initially triggered by infection with herpes simplex or another virus is unknown.

More recently, streptococcal antigens have been found in the lesions (aphthous ulcer and skin lesion) of Behçets disease and lymphocytes from these patients proliferated in vitro when cultured with the streptococcal antigen. It was suggested that in Behçets disease, insufficient anti-streptococcal antibodies 


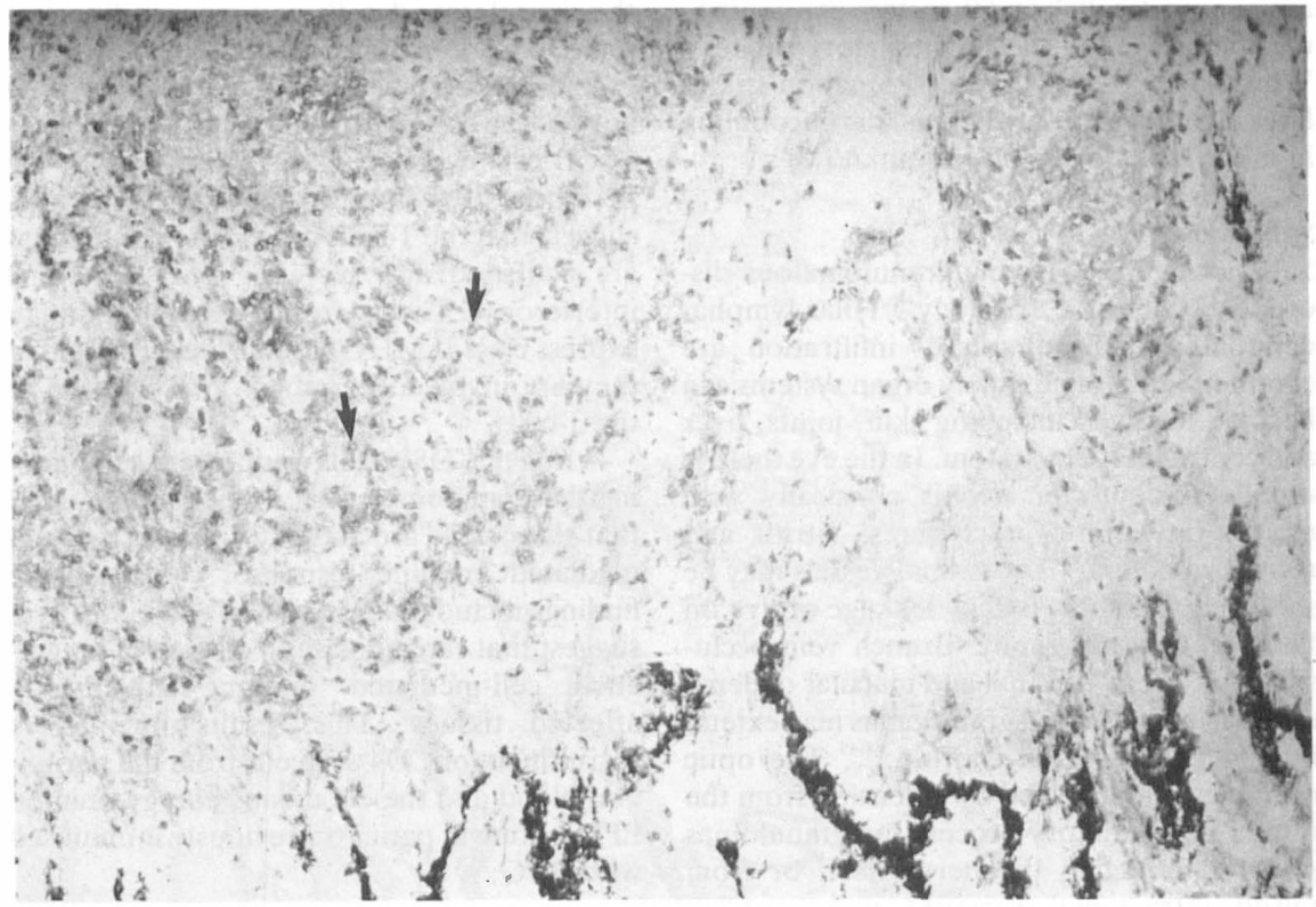

Fig. 3 Sarcoid. Ciliary body infiltrated with CD4+T-cells (arrows). Frozen section $\times 400$.

were formed so that there was not adequate neutralisation of the streptococcal antigens. Other groups have found increased circulating IgA reacting to streptococcus pyogenes antigen, and a significantly higher level of $\operatorname{IgA}$ in the circulating immune complexes in serum from patients with Behçets disease. Although skin testing with streptococcus antigen was unhelpful, lymphocytes from patients with Behçets disease showed a higher stimulation index to the same antigen when co-cultured in vitro, suggesting sensitisation of the lymphocytes to this antigen. ${ }^{61}$ The significance of these findings is uncertain. Some features of the ocular disease seen in Behçets disease were seen in rats after immunisation with polysaccharides extracted from the cell walls of $S$. Pyogenes. ${ }^{62}$

Complexes of IgG and the complement components $\mathrm{C} 3$ and $\mathrm{C} 5$ have been found in the aqueous humour ${ }^{63}$ which are thought to be chemotactic for polymorphonuclear leucocytes. Circulating immune complexes and altered levels of $\mathrm{C} 3$ may be found in the serum of patients with Behçets disease. ${ }^{64}$ Shimada $^{65}$ found an acute reduction in complement levels immediately prior to an attack and suggested it was being taken up by tissue bound immune complexes. It has been shown that there is enhanced neutrophil migration as a result of immune complex mediated damage to the endothelial cells of the blood vessels and in vitro, colchicine can block the enhanced migration of lymphocytes induced by serum from Behçet's patients. This may account, in part, for the therapeutic effects of colchicine seen in some of these patients. ${ }^{66}$

No impairment of cell-mediated immunity was detected in patients with Behçets disease as determined by skin testing with PPD and mumps although a decrease in total numbers of T-cells has been reported. A lower T4:T8 ratio was seen in the peripheral blood in patients with one or more of the major manifestations of Behçets disease including uveitis. Abnormal B-cell function with increased amounts of circulating IgG, IgA, IgM, reduced natural killer cell activity and a decreased ability of their T-lymphocytes to produce and respond to IL-2 have also been reported. ${ }^{67}$

Histological examination of the retina 
reveals numerous areas of vascular occlusion affecting both the arteries and veins. The superficial layers of the retina may undergo necrosis and there is atrophy of the nerve fibre layer secondary to the progressive ischaemia and loss of blood-supply. The affected retinal vessels show thickened basement membranes with mucopolysaccharide deposition. Thrombus is present in the vessel lumen and the area around the vessel is infiltrated with polymorphonuclear leucocytes and lymphocytes. ${ }^{68}$

Although no eyes have to date been examined immunohistopathologically, biopsies of erythema nodosum-like skin lesions have been taken. ${ }^{69}$ Early lesions were characterised by large numbers of infiltrating lymphocytes and macrophages particularly in the perivascular areas. Sixty to eighty per cent of the lymphocytes were found to be T-cells of the CD4+ type with $20-40 \%$ of the T-cells being of the CD $8+$ type. NK cells were found in the infiltrate in $50 \%$ of biopsies examined and only constituted $5 \%$ of the total cellular infiltrate. B-cells were not present. In older lesions, the pathological picture was much more varied and the infiltrate consisted mainly of neutrophils rather than lymphocytes. Similar examination of oral ulcers within three days of development, also showed a predominance of T-lymphocytes in the infiltrate with less than $15 \%$ of the total cells being B-cells. Equal numbers of CD4+ and CD8+ cells were seen in this study. ${ }^{70}$

\section{Discussion}

Although these studies give no information on the aetiology of these inflammatory disorders, they do implicate the CD4+ T-cell as playing a major role in the active inflammatory lesion. Few B-cells are seen in the tissues apart from in the study of the eye with $\mathrm{VKH}$ syndrome but even in this eye, T-cells still greatly outnumber the B-cells. Class II MHC antigens were demonstrated to be present in some resident cells of the eyes suggesting that there is active presentation of antigen to the infiltrating T-cells.

CD4+ T-cells have been shown in vitro to be functionally heterogeneous and recently, murine CD4+ T-cells have been divided into two groups $\left(\mathrm{Th}_{1}\right.$ and $\left.\mathrm{Th}_{2}\right)$ based on which lymphokines they are able to secrete since the latter determine the function of each T-cell. $\mathrm{Th}_{1}$ cells secrete IL- 2 , interferon- $\gamma$ and lymphotoxin whereas $\mathrm{Th}_{2}$ cells secrete IL-4. IL-2 production is important as it has many functions including the maturation of class I MHC restricted cytotoxic T-cells. Interferon- $\gamma$ induces class II MHC expression and thereby enhances local antigen presentation. $\mathrm{Th}_{1}$ CD4+ T-cells may also be cytotoxic but will only kill target cells expressing class II MHC antigens. Lymphotoxin is thought to be one of the cytotoxic lymphokines secreted by these cells although it is not the only one. ${ }^{71}$ IL-4 is a B-cell maturation lymphokine and 'helps' in antibody production by B-cells. The situation in man appears not so clear cut, at least in vitro as CD4+ T-cell clones have been found which secrete both IL-2 and IL-4. ${ }^{72}$ The in vivo situation requires further clarification and it is not known whether the CD4+ T-cell is itself an effector cell or whether its main function is to recruit into the tissues other cell types which actually do the damage.

Current theories of autoimmune diseases, suggest that their aetiology is likely to be a complicated mixture of genetic, immunologic and viral factors. These factors may determine the site of the disease process and therefore its clinical features. If the means by which these diseases are perpetuated in the tissues can be elucidated, it may be possible in the future pharmacologically to switch off lymphokine production by these activated CD4+ cells and prevent further damage occurring. Cyclosporine is a start in that direction as it prevents IL-2 production and release. Until that time, these patients are given intensive immunosuppressive therapy with all its accompanying problems and many will still lose their vision.

Copyright permission obtained for this article from Kluwer Academic Press Ltd.

\section{References}

${ }^{1}$ Lubin J, Albert D, Weinstein M: Sixty-five years of sympathetic ophthalmia. Ophthalmology 1980, 87: 109-21.

${ }^{2}$ Marak G: Recent advances in sympathetic ophthalmia. Surv Ophthalmology 1979, 24: 141-56.

${ }^{3}$ Nussenblatt R, Palestine A, Chan C: Cyclosporine therapy in the treatment of intraocular disease resistant to systemic steroids or cytotoxic agents. Am J Ophthalmol 1983, 96: 275-82.

${ }^{4} \mathrm{Green}$ W: Inflammatory diseases and conditions of 
the eye. In: Spencer W (ed.) Ophthalmic pathology. Vol. III. Philadelphia WB Saunders 1986. pp. 1923-66.

${ }^{5}$ Reynard M, Schulman I, Azen S, Minckler D: Histocompatability antigens in sympathetic ophthalmia. Am J Ophthalmol 1983, 95: 216-21.

${ }^{6}$ Ohno S: Immunogenetic studies on ocular disease. In: Gedhim (ed.): Proceedings of the XV International Congress of Ophthalmology, Rome, May 1986 (in press).

${ }^{7}$ Marak G, Font R, Zimmerman L: Histologic variations related to race in sympathetic opthalmia. Am J Ophthalmol 1974, 78: 935-8.

${ }^{8}$ Kuo P, Lubin J, Ni C, Wang K, Albert D: Sympathetic ophthalmia. Internat Clin Ophthalmol 1982, 22: 125-39.

${ }^{9}$ Jakobiec F, Marboe C, Knowles D, Iwamoto T, Harrison W, Chang S, Coleman D: Human sympathetic ophthalmia. Ophthalmology 1983, 90: 76-95.

${ }^{10}$ Chan C, Ben Ezra D, Rodrigues M, Palestine A, Hsu S, Murphree A, Nussenblatt R: Immunohistochemistry and electron microscopy of choroidal infiltrates and Dalen-Fuchs nodules in sympathetic ophthalmic. Ophthalmology 1984, 92: 580-90.

${ }^{11}$ Chan C, Nussenblatt R, Fujikawa L, Palestine A, Stevens G, Parver L, Luckenbach M, Kuwabara T: Sympathetic Ophthalmia: immunological findings. Ophthalmology 1986, 93: 690-5.

${ }^{12}$ Muller-Hermelink H, Kraus-Mackiv E, Daus W: Early stage of human sympathetic ophthalmia. Arch Ophthalmol 1984, 102: 1353-7.

${ }^{13}$ Boone W, Gupta S, Hansen J, Good R: Lymphocyte subpopulations in patients with sympathetic uveitis. Invest Ophthalmol Vis Sci 1976, 15: 957-60.

${ }^{14}$ Rao N, Xu S, Font R: Sympathetic ophthalmia: An immunohistochemical study of epitheliod and giant cells. Ophthalmology 1985, 92: 1660-2.

${ }^{15}$ Rahi A, Morgan G, Levy I, Dinning W: Immunological investigations in post-traumatic granulomatous and non-granulomatous uveitis. $B r \quad J$ Ophthalmol 1978, 62: 722-8.

${ }^{16}$ Urgancioglu M, Halpern B, Parlebas J, Rebeyrotte $\mathrm{P}$ : Concerning the antigenicity of the constituents of the uvea. Review Immunology (Paris) 1970, 34: 85-97.

${ }^{17}$ Faure J, Dekozak Y, Dorey C, Tuyen C, Tuyen V: Activity of different antigenic preparations from the retina to induce experimental autoimmune uveoretinitis. Arch Ophthalmol (Paris) 1977, 37: 47-60.

${ }^{18}$ Gery I, Mochizuki M, Nussenblatt R: Retinal specific antigens and immunopathogenetic processes they provoke. In: Osborne N, Chader J (eds.): Progress in retinal research. Pergamon Press, Oxford and NY, 1986, pp. 75-109.

${ }^{19}$ Faure J: Autoimmunity and the retina. Current Topics in Eye Research 1980, 2: 215-302.

${ }^{20}$ Marak G: Recent advances in sympathetic ophthalmia. Survey Ophthalmology 1979, 24: 141-56.

${ }^{21}$ Rao N and Marak G: Sympathetic ophthalmia sim- ulating VKH disease. Jap J Ophthalmol 1983, 27: 506-11.

${ }^{22}$ Rao N and Cook G: Sympathetic uveitis. Contem Ophthalmology 1980, 1: 1-6.

${ }^{23}$ Rao N and Wong V: Aetiology of sympathetic ophthalmitis. Trans Ophthalmol Soc UK 1981, 101: 357-60.

${ }^{24}$ Suguira S: Vogt-Koyanagi-Harada Disease. Jap J Ophthalmol 1978, 22: 9-35.

${ }^{25}$ Ohno S, Char D, Kimura S, O'Connor G: VogtKoyanagi-Harada syndrome. Am J Ophthalmol 1977, 83: 735-40.

${ }^{26}$ Schimizu K: Harada's, Beçhets, VKH syndromesare they clinical entities? Trans Am Acad Ophthalmol Otolaryng 1973, 77: 281-90.

${ }^{27}$ Ohnos: Vogt-Koyanagi-Harada's disease. In: Saari K (ed.) Uveitis Update. Elsevier Science Publishers, Amsterdam 1984, pp. 401-5.

${ }^{28}$ Yokoyama M, Matsui Y, Kamashiroya H, O'Donell M, Tseng H, Strydor D, Tessler H, Crisfen R, Zimjewski C: Humoral and cellur immunity studies in patients with VKH syndrome and pars planitis. Invest Ophthalmol Vis Sci 1981, 20: 364-70.

${ }^{29}$ Perry $\mathrm{H}$ and Font R: Clinical and histopathologic observations in severe Vogt-Koyanagi-Harada syndrome. Am J Ophthalmol 1977, 83: 242-54.

${ }^{30}$ Lubin J, Ni C, Albert D: A clinicopathological study of Vogt-Koyanagi-Harada syndrome. Internat Ophthalmol Clin 1982, 22: 141-56.

${ }^{31}$ Chan C, Palestine A, Kuwabara T, Nussenblatt R: Immunopathologic study of Vogt-KoyanagiHarada syndrome. Am J Ophthalmol 1988, 105: 607-11.

${ }^{32}$ Moriyama H, Matsumoto K, Mimura Y: Serum immunoglobulin D in Harada's disease and Behçets disease. Acta Soc Ophthalmol Japan 1976, 80: $480-5$.

${ }^{33}$ Aniga H, Ohno S, Higuchi M, Taniguchi M, Nakamura A, Yoshi T: Immunological studies on lymphocytes in the CSF of patients with Vogt-Koyanagi-Harada disease. Clin Immunol (Jpn) 1988 (in press).

${ }^{34}$ Chan C, Nussenblatt R, Palestine A, Roberge F, BenEzra D: Anti-retinal autoantibodies in VKH syndrome, Behçets disease and sympathetic ophthalmia. Ophthalmology 1985, 92: 1025-8.

${ }^{35}$ Manor R, Livni E, Cohen S: Cell-mediated immunity to human myelin basic protein in Vogt-Koyanagi-Harada syndrome. Invest Ophthalmol Vis Sci 1979, 18: 204-6.

${ }^{36}$ Tagawa Y: Lymphocyte mediated cytotoxicity against melanocyte antigen in Vogt-KoyanagiHarada disease. Jap J Opthalmology 1978, 22: 34-39.

${ }^{37}$ Welch R, Maumenee A, Wahlen H: Peripheral posterior segment inflammation, vitreous opacities and oedema of the posterior pole. Arch Ophthalmol 1960, 64: 540-9.

${ }^{38}$ Pruett R, Brockhurst R, Letts N: Fluorescein angiography of peripheral uveitis. Am J Ophthalmol 1974, 77: 448-53.

${ }^{39}$ Ausberger J, Annesley W, Sergott R, Felberg N, 
Bowman J, Raymond L: Familial pars planitis. Ann Ophthalmol 1981, 13: 553-7.

${ }^{40}$ Maumenee A: Clinical entities in uveitis. Trans Am Acad Ophthalmol, Otolaryng 1970, 74: 473-504.

${ }^{41}$ Pederson J, Kenyon K, Green R, Maumenee E: Pathology of pars planitis. Am J Ophthalmol 1978, 86: 762-74.

${ }^{42}$ Kenyon K, Pederson J, Green W, Maumenee A: Fibroglial proliferation in pars planitis. Trans Ophthalmol Soc UK 1975, 95: 391-7.

${ }^{43}$ Wetzig R, Chan C, Nussenblatt R, Palestine A, Mazur D, Mittal K: Clinical and immunopathological studies of pars planitis in a family. $\mathrm{Br} J$ Ophthalmol 1988, 72: 5-10.

${ }^{44}$ Roberge F, Caspi R, Chan C, Kuwabara T, Nussenblatt R: Long term culture of Muller cells from adult rats in the presence of activated lymphocyte/ monocyte products. Curr Eye Res 1985, 4: 975-82.

${ }^{45}$ Roberge F, Caspi R, Nussenblatt R: Glial retinal cells produce IL-1 activity and have dual effect on autoimmune T-helper lymphocytes. J Immunol 1988, 140: 2193-6.

${ }^{46}$ Mitchell D, Scadding J, Heard B, Hinson K: Sarcoidosis: Histopathological definition and clinical diagnosis. J Clin Pathol 1977, 30: 395-408.

${ }^{47}$ James D: Ocular sarcoidosis. Ann New York Acad Sci 1986, 465: 551-63.

${ }^{48}$ Gass J and Olsen C: Sarcoidosis with optic nerve and retinal involvement: A clinicopathological case report. Trans Am Acad Ophthalmol Otolaryngol 1975, 77: 739-50.

${ }^{49}$ Gould $\mathrm{H}$ and Kaufman H: Sarcoid of the fundus. Arch Ophthalmol 1961, 65: 453-6.

${ }^{50}$ Daniele R, Dauber J, Rossman M: Immunological abnormalities in sarcoidosis. Ann Internal Med 1980, 92: 406-16.

${ }^{51}$ Semenzato G, Agostini C, Zambello R, et al: Activated $T$-cells with immunoregulatory functions at different sites of involvement in sarcoidosis. Ann New York Acad Sci 1986, 465: 56-73.

${ }^{52}$ Chan C, Wetzig R, Palestine A, Kuwabara T, Nussenblatt R: Immunohistopathology of ocular sarcoidosis. Arch Ophthalmol 1987, 105: 1398-402.

${ }^{53}$ Modlin R, Hofman F, Meyer P, Sharma O, Taylor C, Rea T: In situ demonstration of T-lymphocyte subsets in granulomatous inflammation. Clin Exp Immunol 1983, 51: 430-8.

${ }^{54}$ Leung K and Ada G: Two T-cell populations mediate DTH to murine influenza infection. Scand $J$ Immunol 1980, 12: 481-5.

${ }^{55}$ Hancock W, Kobzik L, Colby A, O'Hara C, Cooper A, Godleski J: Detection of lymphokines and lymphokine receptors in pulmonary sarcoidosis. Am J Pathol 1986, 123: 1-8.

${ }^{56}$ Ohno S, Kakayama E, Sugiura S, Itakura K, Aoki K, Aizawa M: Specific histocompatibility antigens associated with Behçets disease. Am J Ophthalmol 1975, 80: 636.

${ }^{57}$ Lehner T, Batchelor J, Challacombe S, Kennedy L: An immunogenetic basis for the tissue involvement in Behçets syndrome. Immunol 1979, 37: 895-900.

${ }^{58}$ O'Connor G: Behçets disease in E. Klein (ed.) Sym- posium on medical and surgical diseases of the retina and vitreous pp. 199. St Louis, Mosby.

${ }^{59}$ Eglin R, Lehner T, Subak-Sharpe J: Detection of RNA complementary to herpes simplex virus in mononuclear cells from patients with Behçets syndrome and recurrent oral cells. Lancet 1982, ii: 1356-61.

${ }^{60}$ Bonass W, Stewart J, Chamberlain M, Halliburton I: Molecular studies in Behçets disease. In: Lehner $\mathrm{T}$ and Barnes $\mathrm{C}$ (eds.) Recent advances in Behçets disease 1986. pp. 37-41. Royal Society of Medicine Services, London.

${ }^{61}$ Mizushima Y : Recent research into Behçets disease in Japan. Int J Tissue React 1988, 10: 59-65.

${ }^{62}$ Miyangana Y: Annual report of Behçets Disease Research Committee of Japan 1987. p. 181.

${ }^{63}$ Shimada K, Yaoita H, Shikano S: Chemotactic activity in aqueous humour of patients with Behçets disease. Jap J Ophthalmol 1972, 16: 84-92.

${ }^{64}$ Williams B and Lehner T: Immune complexes in Behçets syndrome and recurrent oral ulcerations. Br Med J 1977, 1: 1387-9.

${ }^{65}$ Shimada K, Kogure M, Kawashima T, Nishioka K: Reduction in complement in Behçets disease and drug allergy. Med Biol 1974, 52: 234-9.

${ }^{66}$ Jorizzo J, Schmalsteig F, Solomon A, Taylor R, Cavallo T: Studies of circulating immune complexes, neutrophils and effects of oral colchicine or thalidomide in Behçets discase. In: Lehner $T$ and Barnes C (eds.) Recent advances in Behçets disease. 1986. pp. 89-96. Royal Society of Medicine Services, London.

${ }^{67}$ Lehner T and Barnes C (eds.): Recent Advances in Behçets disease. Royal Society of Medicine Services, London 1986.

${ }^{68}$ Smolin G and O'Connor G: Immunologic diseases affecting the uveal tract and retina. In: Ocular Immunology 1986, p. 312-315. Little, Brown and Co., Boston USA.

${ }^{69}$ Yamana S, Jones S, Shimamoto T, Shiota T, Aoyama T, Takasugi K: Immunohistological analysis of lymphocytes infiltrating the terminal ileum in a patient with intestinal Behçets disease. In: Lehner $T$ and Barnes $C$ (eds.): Recent advances in Behçets disease. 1986. pp. 129-130. Royal Society of Medicine Services, London.

${ }^{70}$ Poulter L, Lehner T, Duke O: Immunohistological investigation of recurrent oral ulcers and Behçets disease. In: Lehner $\mathrm{T}$ and Barnes $\mathrm{C}$ (eds.): Recent advances in Behçets disease 1985. pp. 123-128. Royal Society of Medicine Services, London.

${ }^{71}$ Jongeneel C, Nedospasov S, Plaetinck, Naquet P, Cerottini J: Expression of the tumour necrosis factor locus is not necessary for the cytolytic activity of T-lymphocytes. J Immunol 1988, 140: 1916-22.

${ }^{72}$ Paliard X, Malefit R, Yssel H, Blanchard D, Chretien I, Abrams J, Vries J, Spits H: Simulataneous production of IL-2, IL-4 and interferon- $\gamma$ by activated human CD4+ and CD8+ T-cell clones. $J$ Immunol 1988, 141: 849-55. 